\title{
Endoscopic submucosal tunnel dissection for early squamous cell carcinoma of the esophagus
}

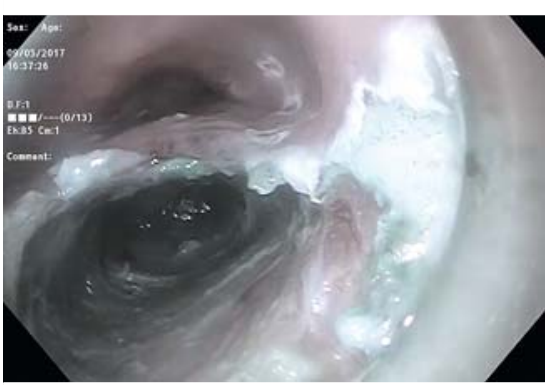

- Fig. 1 Endoscopic view of the tunnel during resection.

We report the case of an 83-year-old man with past medical history of hypertension who was initially referred for the evaluation of newly diagnosed squamous cell cancer (SCC) of the esophagus. An endoscopic ultrasound was performed and showed a medium-sized flat lesion in the mid-esophagus, which appeared to be invading the muscularis mucosa (T1a). During a multidisciplinary meeting, it was decided that the patient would benefit from an endoscopic submucosal dissection of the lesion.

A medium-sized, flat lesion with no bleeding and no stigmata of recent bleeding was found in the upper third of the esophagus, $26-29 \mathrm{~cm}$ from the incisors. The mass was nonobstructing and partially circumferential. Using optical coherence tomography (Ninepoint Medical, Bedford, Massachusetts, USA), the lesion was confirmed to be $\mathrm{T} 1$ without invasion into the submucosa.

A GIF-H180 endoscope (Olympus, Tokyo, Japan) with a transparent cap was advanced to lesion. The borders of the lesion were marked circumferentially with a multipurpose knife (T knife; Erbe USA, Marietta, Georgia, USA). First, $10 \mathrm{~mL}$ of saline with methylene blue was injected proximally to the lesion. A tunnel was created to the distal margin of the lesion and opened laterally. There was significant scaring in the submucosal space making



$\checkmark$ Video 1 Technique of endoscopic submucosal tunnel dissection in the esophagus.

dissection difficult ( $>$ Fig. 1, $>$ Video 1 ). After careful dissection of the submucosal space, the lateral and distal borders were dissected with an IT2 knife (Olympus, Center Valley, Pennsylvania, USA). The lesion was completely removed en bloc and sent for histologic evaluation. The GIF-XP180 scope was inserted through the right nostril into the stomach. Enteral feeding was started in order to allow the site to heal by secondary intention.

On 1-week follow-up, the patient had no complaints and was tolerating solid food. Based on the pathology, the resection margins were negative for carcinoma and dysplasia.

SCC of the esophagus is the most common histologic type of esophageal cancer in Asia, with lower incidence in the United States [1]. Historically, surgery was thought to be the gold standard treatment for these patients; however, esophagectomy is associated with high rates of complications and mortality [2]. In recent years, many studies have shown that endoscopic therapy, particu- larly endoscopic submucosal dissection (ESD), is comparable to surgical resection but with lower morbidity [3]. However, esophageal ESD could be more difficult owing to the thinner wall and narrow lumen of the esophagus. Therefore, inspired by peroral endoscopic myotomy, endoscopic submucosal tunnel dissection (ESTD) has been developed for en bloc resection of these lesions, with promising results $[4,5]$. This case demonstrates successful management of early SCC of the esophagus with ESTD.

Endoscopy_UCTN_Code_TTT_1AO_2AG

Competing interests

Michel Kahaleh MD: has received grant support from Boston Scientific, Fujinon, EMcison, Xlumena Inc., W.L. Gore, MaunaKea, Apollo Endosurgery, Cook Endoscopy, ASPIRE Bariatrics, GI Dynamics, NinePoint Medical, Merit Medical, Olympus and MI Tech. He is a consultant for Boston Scientific, Xlumena Inc., Concordia Laboratories Inc, ABBvie, and MaunaKea Tech. 
Iman Andalib, Enad Dawod, Monica Saumoy, Melanie Johncilla, Amy Tyberg, Michel

\section{Kahaleh}

Division of Gastroenterology and Hepatology, New York Presbyterian Hospital/Weill Cornell Medical Center, New York, United States

\section{Corresponding author}

\section{Michel Kahaleh, MD}

Division of Gastroenterology and Hepatology, Weill Cornell Medical College, 1305 York Avenue, 4th Floor, New York, NY 10065, United States

Fax: +1-646-962-0110

mkahaleh@gmail.com

\section{References}

[1] Yip HC, Chiu PW. Endoscopic diagnosis and management of early squamous cell carcinoma of esophagus. J Thorac Dis 2017; 9 (Suppl. 08): S689-S696

[2] Lizuka T, Kikuchi D, Hoteya S et al. Efficacy and safety of endoscopic submucosal dissection for superficial cancer of the cervical esophagus. Endosc Int Open 2017; 5: E736 E741

[3] Prasad GA, Wu TT, Wigle DA et al. Endoscopic and surgical treatment of mucosal (T1a) esophageal adenocarcinoma in Barrett's esophagus. Gastroenterology 2009; 137: $815-823$

[4] Linghu E, Feng X, Wang X et al. Endoscopic submucosal tunnel dissection for large esophageal neoplastic lesions. Endoscopy 2013; 45: 60-62

[5] Huang R, Cai H, Zhao X et al. Efficacy and safety of endoscopic submucosal tunnel dissection for superficial esophageal squamous cell carcinoma: a propensity score matching analysis. Gastrointest Endosc 2017; 86: $831-838$

\section{Bibliography}

DOI https://doi.org/10.1055/s-0043-125359

Published online: 19.1.2018

Endoscopy 2018; 50: E88-E89

(c) Georg Thieme Verlag KG

Stuttgart · New York

ISSN 0013-726X

\section{ENDOSCOPY E-VIDEOS}

https:/|eref.thieme.de/e-videos

回的 Endoscopy E-Videos is a free access online section, reporting 回: on interesting cases and new techniques in gastroenterological endoscopy. All papers include a high quality video and all contributions are freely accessible online.

This section has its own submission website at

https://mc.manuscriptcentral.com/e-videos 